\title{
Chlamydia trachomatis IgG Antibody Measurement
}

National Cancer Institute

\section{Source}

National Cancer Institute. Chlamydia trachomatis Ig G Antibody Measurement. NCI

Thesaurus. Code C100466.

The determination of the amount of Chlamydia trachomatis IgG antibody present in a sample. 